\title{
KEMAMPUAN BERPIKIR KRITIS PESERTA DIDIK PADA PEMBELAJARAN IPA MATERI PENGELOLAAN LINGKUNGAN DENGAN PENDEKATAN KETERAMPILAN PROSES SAINS DI SMPN 16 MANDAI KABUPATEN MAROS
}

\author{
Haryati, Firdaus Daud, Muhammad Junda \\ Pendidikan Biologi Pascasarjana, Universitas Negeri Makassar \\ Email:Haryatisutia@yahoo.co.id
}

\begin{abstract}
Abstarak: Hasil penelitian menunjukkan aktivitas belajar model STAD dengan pendekatan KPS berada pada kategori aktif; aktivitas belajar model STAD dengan pendekatan CTL berada pada kategori cukup aktif; kemampuan berpikir kritis model STAD dengan pendekatan KPS berada pada kategori tinggi; kemampuan berpikir kritis model STAD dengan pendekatan CTL pada kategori sedang; ada perbedaan yang signifikan aktivitas belajar model STAD dengan pendekatan KPS dan model STAD dengan pendekatan CTL dan ada perbedaan kemampuan berpikir kritis model STAD dengan pendekatan KPS dan model STAD dengan pendekatan CTL peserta didik di SMPN 16 Mandai Kabupaten Maros.
\end{abstract}

Kata Kunci: Stad, Kps, Ctl, Aktivitas, Kemampuan Berpikir Kritis.

\section{THE CAPACITY TO THINK CRITICAL SCHOOL TUITION IN LEARNING IPA MATTER ENVIRONMENTAL MANAGEMENT WITH THE APPROACH SKILL THE PROCESS OF SCIENCE SMPN 16 MANDAI DISTRICT MAROS}

Abstarak: The research results show activity learn model STAD by approach KPS be in the active; activity learn model STAD by approach CTL be in the quite active; ability to think critically model STAD by approach KPS be in the high; ability to think critically model STAD by approach CTL at the; there are significant differences activity learn model STAD by approach KPS and models STAD by approach CTL and there is a difference in the capacity think critically model STAD by approach KPS and models STAD by approach CTL students 16 mandai school district Maros.

Keywords: Stad, Kps, Ctl, Activity, Critical Thinking

Proses belajar mengajar, kebanyakan pendidik hanya terpaku pada buku teks sebagai satu-satunya sumber belajar mengajar. Hal ini yang menjadi kelemahan dalam 
pembelajaran IPA adalah masalah tehnik penilaian pembelajaran yang tidak akurat dan menyeluruh. Proses penilaian yang dilakukan selama ini semata-mata menekankan pada penguasaan konsep yang dijaring dengan tes tertulis objektif dan subjektif sebagai alat ukurnya. Dengan cara penilaian seperti ini, berarti pengujian yang dilakukan oleh pendidik baru mengukur penguasaan materi saja dan itu pun hanya meliputi ranah kognitif tingkat rendah. Keadaan seperti ini merupakan salah satu indikasi adanya kelemahan pembelajaran disekolah (Susanto, 2013).

Berdasarkan hasil wawancara dengan pendidik IPA di SMP Negeri 16 Mandai Kabupaten Maros dan pengamatan dalam proses pembelajaran yang menunjukkan bahwa keterampilan proses peserta didik masih kurang serta rata-rata peserta didik memperoleh nilai dibawah KKM = 71 yang telah ditetapkan sekolah. Peserta didik belum mampu menemukan sendiri konsep biologi yang dipelajarinya, proses belajar yang menggunakan metode diskusi dimana ada peserta didik yang mendominasi didalam kelompoknya pada proses pembelajaran. Pembelajaran diskusi pada peserta didik menyebabkan pengetahuan tidak merata karena ada beberapa peserta didik yang hanya santai dalam kelompok dan soal-soal evaluasi yang diberikan belum berorientasi untuk mengembangkan kemampuan berpikir kritis. Hal ini mengakibatkan rendahnya kemampuan berpikir kritis peserta didik. Akibat hal tersebut peserta didik kesulitan menganalisis informasi yang ada, cenderung menerima informasi yang disampaikan maupun yang tertulis dalam buku, dan pasif dalam mengajukan pertanyaan maupun menjawab pertanyaan dari masalah yang diajukan pendidik, serta mengemukakan ide ataupun gagasan penyelesaikan masalah.

Menurut Nurhayati (2011), jika pendidik hanya mengajarkan fakta, tanpa memperhatikan proses bagaimana fakta itu terungkap, maka fakta yang diajarkan itu tidak sepenuhnya dapat dipahami oleh peserta didik. Bahkan peserta didik dapat menganggap bahwa sains hanya merupakan segudang informasi. Untuk dapat memahami suatu fakta atau konsep biasanya peserta didik perlu bekerja dengan objek-objek yang konkret, melakukan ekplorasi, manipulasi ide, sehingga diperoleh data-data, tidak sekedar menghafal. Untuk itu dalam pembelajaran sains perlu pendekatan proses. Pendekatan proses dalam pembelajaran sains didasarkan atas pengamatan terhadap apa yang dilakukan oleh ilmuawan. Proses-proses yang dijabarkan dari kegiatan apa yang dilakukan oleh seorang ilmuawan itu yang disebut keterampilan proses.

Menurut Hamalik (2014), ada 5 jenis kemampuan yang hendak dikemabngkan melalui proses pembelajaran berdasarkan pendekatan keterampilan proses dasar, yaitu; 1) Mengamati, dilakukan dengan menggunakan alat indera seperti mata untuk mengumpulkan data informasi yang relevan dengan kepentingan belajarnya, sehinggga hasil belajar dapat meningkat; 2) Menafsirkan (inferensi), memiliki keterampilan menafsirkan fakta, data informasi atau peristiwa, keterampilan ini diperlukan untuk melakukan percobaan atau penelitian sederhana; 3) Meramalkan (prediksi), mampu memiliki keterampilan menghubungkan data, fakta dan informasi, peserta didik dituntut 
terampil mengantisipasi meramalkan kegiatan atau peristiwa yang mungkin terjadi pada peristiwa yang akan datang; 4) Mengklasifikasikan, harus terampil mengenal perbedaan dan persamaan atas hasil pengamatannya terhadap suatu objek serta mengadakan klasifikasi berdasarkan ciri khusus, tujuan, atau kepentingan tertentu, pembuatan klasifikasi memerlukan kecermatan dalam pengamatan; 5) Bertanya atau mengkomunikasikan, peserta didik harus mampu menanyakan hal-hal yang belum dimengerti dan menyampaikan secara sistematis baik proses maupun hasil belajar kepada peserta didik yang lain.

STAD (Student Teams Achievement Divisions) merupakan salah satu pendekatan dalam pembelajaran kooperatif yang paling sederhana, yang dikembangkan oleh Robert Slavin di Universitas John Hopkin, dan merupakan sebuah pendekatan yang baik untuk guru yang baru menerapkan model pembelajaran kooperatif di kelas dan kooperatif tipe STAD telah digunakan secara luas seperti pada pelajaran matematika, seni, bahasa, ilmuilmu sosial, dan sains. Pembelajaran kooperatif tipe STAD dibagi menjadi lima komponen utama yaitu: presentasi kelas (class presentations), belajar kelompok (teams), kuis (quizzes), peningkatan skor individu (individual improvement scores), dan penghargaan kelompok (team recognition) (Slavin, 2010).

Pendekatan kontekstual memiliki landasan pada falsafah belajar yakni kontruktivisme. Kontruktivisme menekankan bahwa belajar tidak hanya sekedar menghafal, melaikan siswa mengkontruksi pengetahuan di benaknya. Pengetahuan tidak dapat dipisah-pisahkan menjadi fakta-fakta atau proposisi yang terpisah, tetapi mencerminkan keterampilan yang dapat diterapkan. Artinya, pendekatan kontekstual bersifat pragmatis (Nigrum, 2009). Menurut Depdiknas (2006), pembelajaran IPA sebaiknya dilaksanakan untuk menumbuhkan kemampuan berpikir, bekerja dan bersikap ilmiah serta mengkomunikasikan sebagai aspek penting kecakapan hidup. Oleh karena itu pembelajaran IPA di SMP/MTs menekankan pada pemberian pengalaman belajar secara langsung melalui penggunaan dan pengembangan keterampilan proses dan sikap ilmiah. Keterampilan proses dalam diri peserta didik dapat dikembangkan melalui pendekatan keterampilan proses sains.

Beberapa hasil penelitian sebelumnya menunjukkan bahwa pendekatan keterampilan proses. Disimpulkan bahwa pendekatan KPS pada pembelajaran materi pengelolaan lingkungan berpengaruh terhadap peningkatkan kemampuan berpikir kritis peserta didik (Prayoga, 2013). Berdasarkan latar belakang masalah yang dipaparkan diatas, tujuan dari penelitian ini adalah sebagai berikut: (1) Untuk mengetahui aktivitas belajar melalui model pembelajaran STAD dengan Pendekatan Keterampilan Proses Sains dan peserta didik di SMPN 16 Mandai Kabupaten Maros, (2) Untuk mengetahui aktivitas belajar melalui model pembelajaran STAD dengan pendekatan Kontekstual peserta didik di SMPN 16 Mandai Kabupaten Maros, (3) Untuk mengetahui kemampuan berpikir kritis melalui model pembelajaran STAD dengan Pendekatan Keterampilan 
Proses Sains dan peserta didik di SMPN 16 Mandai Kabupaten Maros, (4) Untuk mengetahui kemampuan berpikir kritis melalui model pembelajaran STAD dengan pendekatan kontekstual peserta didik di SMPN 16 Mandai Kabupaten Maros, (5) Untuk mengetahui perbedaan aktivitas belajar melalui model pembelajaran STAD dengan Pendekatan Keterampilan Proses Sains dan melalui model pembelajaran STAD dengan pendekatan kontekstual peserta didik di SMPN 16 Mandai Kabupaten Maros, dan (6) Untuk mengetahui perbedaan Kemampuan berpikir kritis melalui model pembelajaran STAD dengan Pendekatan Keterampilan Proses Sains dan melalui model pembelajaran STAD dengan pendekatan kontekstual peserta didik di SMPN 16 Mandai Kabupaten Maros.

\section{METODE PENELITIAN}

Jenis penelitian ini adalah Quasi Experimental Desain dengan Nonequivalent Control Group Design. Populasi dalam penelitian ini adalah seluruh rombel kelas VII semester genap SMPN 16 Mandai tahun ajaran 2015/2016 yang terdiri dari 6 rombel. Pengambilan sampel dilakukan dengan teknik random. Populasi di kelas VII sebanyak 193 peserta didik. Rombel yang dimaksud VI1A dengan 33 peserta didik dibelajarkan model STAD dengan pendekatan (KPS) sebagai kelompok eksperimen dan VIIB dengan jumlah 30 peserta didik dipembelajarkan model STAD dengan pendekatan CTL sebagai kelas kontrol. Pengumpulan data aktivitas saat proses pembelajaran dan kemampuan berpikir kritis sesudah proses pembelajaran. Data dianalisis secara deskriptif dan inferensial (menggunakan statistic uji independent Sample T-tes dengan program SPSS 20,0), pada taraf signifikansi hipotesis digunakan $\alpha=0,05$.

\section{HASIL DAN PEMBAHASAN}

Berdasarkan hasil data aktivitas belajar melalui model Pembelajaran STAD dengan Pendekatan Keterampilan Proses Sains Peserta Didik di SMP Negeri 16 Mandai Kab. Maros diperoleh data pada Tabel 1.

Tabel 1 Hasil analisis deskriptif aktivitas belajar kelas ekperimen

\begin{tabular}{ll}
\hline StatistiK & Aktivitas \\
\hline Jumlah sampel & 33 \\
Mean & 6,94 \\
Median & 7,00 \\
Standar deviasi & 1,56 \\
Varians & 2,43 \\
Nilai tertinggi & 9,00 \\
Nilai terendah & 3,00 \\
\hline
\end{tabular}

Distribusi persentase frekuensi data aktivitas belajar melalui model pembelajaran STAD dengan Pendekatan Keterampilan Proses Sains dapat dilihat pada Tabel 2. 
Tabel 2 Distribusi Frekuensi data Aktivitas belajar kelas ekprimen

\begin{tabular}{cccc}
\hline Interval & Kategori & Frekuensi & Persentase \% \\
\hline $8-9$ & Sangat Aktif & 12 & 36 \\
$6-7$ & Aktif & 16 & 48 \\
$4-5$ & Cukup Aktif & 4 & 12 \\
$2-3$ & Kurang Aktif & 1 & 3 \\
$0-1$ & Tidak Aktif & 0 & 0 \\
\hline Jumlah & & 33 & 100
\end{tabular}

Berdasarkan Tabel 2 data tersebut dapat mengindikasi bahwa kebanyakan peserta didik kelas eksperimen melalui model pembelajaran STAD dengan Pendekatan Keterampilan Proses Sains kelas VIIA di SMP Negeri 16 Mandai dianggap aktif.

Tabel 3 Hasil analisis deskriptif aktivitas belajar kelas kontrol

\begin{tabular}{ll}
\hline Statistik & Aktivitas \\
\hline Jumlah sampel & 30 \\
Mean & 5,93 \\
Median & 6,00 \\
Standar deviasi & 1,87 \\
Varians & 3,51 \\
Nilai tertinggi & 9,00 \\
Nilai terendah & 2,00 \\
\hline
\end{tabular}

Distribusi data persentase aktivitas belajar melalui pembelajaran STAD dengan Pendekatan Kontekstual dapat dilihat pada Tabel 4.

Tabel 4 Distribusi data Aktivitas belajar kelas kontrol

\begin{tabular}{cccc}
\hline Interval & Kategori & Frekuensi & Persentase \% \\
\hline $8-9$ & Sangat Aktif & 7 & 23 \\
$6-7$ & Aktif & 10 & 33 \\
$4-5$ & Cukup Aktif & 11 & 37 \\
$2-3$ & Kurang Aktif & 2 & 7 \\
$0-1$ & Tidak Aktif & 0 & 0 \\
\hline Jumlah & & 30 & 100
\end{tabular}

Berdasarkan data Tabel 4 tersebut dapat mengindikasikan bahwa kebanyakan peserta didik kelas kontrol melalui model pembelajaran STAD dengan pendekatan kontekstual kelas VIIB di SMP Negeri 16 Mandai dianggap cukup aktif

Tabel 5 Hasil analisis deskriptif kemampuan berpikir kritis belajar kelas eksperimen

\begin{tabular}{ll}
\hline Statistik & $\begin{array}{l}\text { Kemampuan berpikir } \\
\text { kritis }\end{array}$ \\
\hline Jumlah sampel & 33 \\
Mean & 73,92 \\
Median & 71,43 \\
Standar deviasi & 14,95 \\
Varians & 223,62 \\
Nilai tertinggi & 96,43 \\
Nilai terendah & 46,43 \\
\hline
\end{tabular}


Distribusi data persentase dan frekuansi kemampuan berpikir kritis belajar melalui pembelajaran STAD dengan Pendekatan Keterampilan Proses Sains dapat dilihat pada Tabel 6.

Tabel 6 Distribusi data Kemampuan Berpikir Kritis belajar kelas eksperimen

\begin{tabular}{cccc}
\hline Interval skor & Kategori & Frekuensi & Persentase \% \\
\hline $81-100$ & Sangat Tinggi & 11 & 33 \\
$61-80$ & Tinggi & 15 & 45 \\
$41-60$ & Sedang & 7 & 21 \\
$21-40$ & Rendah & 0 & 0 \\
$0-20$ & Sangat Rendah & 0 & 0 \\
\hline Jumlah & & 33 & 100
\end{tabular}

Berdasarkan data Tabel 6 tersebut dapat mengindikasi bahwa kebanyakan peserta didik kelas eksperimen melalui model pembelajaran STAD dengan pendekatan Keterampilan Proses Sains peserta didik SMP Negeri 16 Mandai kelas VIIA kemampuan berpikir kritis kategori tinggi.

Tabel 7 Hasil analisis deskriptif kemampuan berpikir kritis belajar kelas kontrol

\begin{tabular}{ll}
\hline Statistik & Kemampuan berpikir kritis \\
\hline Jumlah sampel & 30 \\
Mean & 63,69 \\
Median & 62,50 \\
Standar deviasi & 11,87 \\
Varians & 140,81 \\
Nilai tertinggi & 85,71 \\
Nilai terendah & 39,39 \\
\hline
\end{tabular}

Distribusi data persentase dan frekuensi kemampuan berpikir kritis belajar melalui model pembelajaran STAD dengan Pendekatan Kontekstual dapat dilihat pada Tabel 8.

Tabel 8 Distribusi data Kemampuan Berpikir Kritis belajar kelas kontrol

\begin{tabular}{cccc}
\hline $\begin{array}{c}\text { Interval } \\
\text { skor }\end{array}$ & Kategori & Frekuensi & Persentase \% \\
\hline $81-100$ & Sangat Tinggi & 2 & 7 \\
$61-80$ & Tinggi & 13 & 43 \\
$41-60$ & Sedang & 14 & 47 \\
$21-40$ & Rendah & 1 & 3 \\
$0-20$ & Sangat Rendah & 0 & 0 \\
\hline Jumlah & & 30 & 100
\end{tabular}

Berdasarkan data Tabel 8 tersebut dapat mengindikasi bahwa kebanyakan peserta didik kelas kontrol melalui model pembelajaran STAD dengan Pendekatan Kontekstual peserta didik SMP N 16 Mandai kelas VIIB di SMP Negeri 16 Mandai kemampuan berpikir kritis berada pada kategori sedang.

Hasil data aktivitas melalui pembelajaran STAD dengan Pendekatan Keterampilan Proses Sains kelas eksperimen.peserta didik kategori aktif. Yaqin (2005) menyatakan, aktivitas atau kegiatan praktikum memengang perana penting dalam 
pendidikan IPA, karena memberikan metode ilmiah kepada peserta didik. Peserta didik dilatih membaca data secara obyektif dan mengambil kesimpulan dari suatu kegiatan praktikum apabila sudah banyak fakta yang mendukungnya. Peserta didik dituntut untuk menyadari keterbatasan pengukuran dalam penelitian dan mengerti makna suatu teori. Dari hasil pembahasan diatas dapat ditarik mengindikasi bahwa melalui pembelajaran STAD dengan Pendekatan Keterampilan Proses Sains kelas eksperimen persentase peserta didik berada pada kategori aktif. Menandakan bahwa proses pembelajaran melalui pembelajaran STAD dengan Pendekatan Keterampilan Proses Sains kelas eksperimen dianggap sangat efektif karena kategori aktivitas terpenuhi.

Melalui pembelajaran STAD dengan Pendekatan Kontekstual kelas kontrol persentase peserta didik berada pada kategori Aktif. Menandakan bahwa proses pembelajaran melalui pembelajaran STAD dengan Pendekatan Kontekstual kelas kontrol dianggap efektif karena kategori aktivitas terpenuhi. Nasution dalam Nugroho, dkk (2009) menyatakan aktivitas merupakan asas yang penting dalam pembelajaran, sebab belajar sendiri merupakan kegiatan, tanpa kegiatan tak mungkin seseorang belajar. Segala pengetahuan dapat diperoleh melalui pengamatan, dan pengalaman.

Nilai tes kemampuan berpikir kritis peserta didik yang diberikan setelah proses pembelajaran melalui STAD dengan Pendekatan Keterampilan Proses Sains kelas eksperimen. Kemampuan berpikir kritis peserta didik terdapat lima aspek sebagai indikator dalam berpikir kritis yaitu merumuskan masalah, memberikan argument, melakukan induksi, melakukan evaluasi, dan mengambil keputusan dan tindakan. Berdasarkan hasil penelitian, kemampuan berpikir kritis peserta didik di SMP Negeri 16 Mandai berada pada kategori Tinggi. Hal ini didukung oleh pendapat Rustaman dalam Noviyanti (2014) bahwa keterampilan mengamati merupakan keterampilan paling dasar dalam proses memperoleh ilmu pengetahuan serta merupakan hal terpenting untuk mengembangkan keterampilan proses yang lain. Kegiatan pengamatan merupakan tanggapan terhadap berbagai objek dan peristiwa alam dengan menggunakan panca indera, sehingga peserta didik mampu untuk mempelajari materi pengelolaan lingkungan. merumuskan masalah, memberikan argument, melakukan induksi, melakukan evaluasi, dan mengambil keputusan dan tindakan kegiatan-kegiatan tersebut, merupakan aspek kemampuan berpikir kritis. Santoso (2010), menyatakan bahwa melalui pembelajaran dengan menggunakan pendekatan KPS di kelas eksperimen pada penelitian ini dilakukan secara kelompok. Pembentukan kelompok ini dimaksudkan agar peserta didik mampu membangun pengetahuan secara bersama-sama. Melalui kerja kelompok memungkinkan peserta didik dapat mengungkapkan gagasan, mendengarkan pendapat teman, memberikan ide dan melatih komunikasi dengan orang lain. Sehingga dapat mendorong peserta didik untuk berpikir kritis.

Curtodan (2005) dalam Noviyanti (2014) menyatakan bahwa, berpikir kritis dapat dikembangkan dengan memperkaya pengalaman peserta didik yang bermakna, 
pengalaman tersebut dapat berupa kesempatan berpendapat secara lisan maupun tulisan layaknya seorang ilmuwan. Pendekatan keterampilan proses sains memberikan kesempatan tersebut kepada peserta didik melakukan pembelajaran seperti ilmuan sehingga akan meningkatkan kemampuan berpikir kritis peserta didik nantinya pada materi pengelolaan lingkungan. Ada perbedaan aktivitas peserta didik pada kedua pendekatan pembelajaran tersebut. Pendekatan keterampilan proses melakukan praktikum akan lebih menarik perhatian peserta didik dibandingkan dengan hanya pengamatan gambar yang terdapat dalam LKPD yang terdapat pada kelas kontrol.

Kelebihan penerapan model STAD berorientasi pada pendekatan keterampilan proses sains adalah peserta didik berusaha mencari pengetahuan sendiri dengan keterampilan proses yang dimiliki dan melati peserta didik melaksanakan praktikum seperti yang dilakukan oleh para ilmuan sehingga peserta didik mampu bekerja dan berdiskusi kelompok serta meningkatkan aktivitas peserta didik karena pembelajaran berpusat pada peserta didik. Berdasarkan hasil analisis inferensial dengan menggunakan uji independent Sample T-tes menunjukkan ada perbedaan secara signifikan pada kemampuan berpikir kritis peserta didik yang melalui model pembelajaran STAD dengan pendekatan pendekatan keterampilan proses sains dan melalui model pembelajarlan STAD dengan pendekatan kontekstual peserta didik di SMP Negeri 16 Mandai Kabupaten Maros.

Pendekatan keterampilan proses yang diterapkan pada pembelajaran mampu mengembangkan kemampuan-kemampuan yang dimiliki serta menekankan bagaimana belajar menemukan pengetahuannya sendiri dan mengelola perolehannya. Dengan menemukan konsep secara mandiri maka peserta didik lebih mudah memahami konsep temuan orang lain. Dalam menemukan konsepnya sendiri peserta didik dilatih menggunakan kemampuannya untuk menyelidiki secara sistematis dan kritis sehingga peserta didik mampu merumuskan pengetahuan yang diperoleh. Menurut Haryono (2009), Pendekatan keterampilan proses bertolak dari suatu pandangan bahwa setiap peserta didik memiliki potensi yang berbeda, dan dalam situasi yang normal, mereka dapat mengembangkan potensinya secara optimal. Oleh karena itu, tugas guru adalah memberikan kemudahan kepada peserta didik dengan menciptakan lingkungan yang kondusif agar semua peserta didik dapat berkembang secara optimal. Sejalan dengan pendapat tersebut maka pendekatan keterampilan proses akan lebih mengoptimalkan kemampuan berpikir kritis peserta didik dibandingkan dengan pendekatan kontekstual.

Kedua pendekatan mampu meningkatkan kemampuan berpikir kritis sejalan dengan penelitian yang dilakukan oleh Syahbana (2012) pendekatan Contextual Teaching Learning meningkatkan kemampuan berpikir kritis matematika. Serta hasil penelitian yang dilakukan Noviyanti (2014), menyimpulkan bahwa pendekatan keterampilan proses sains berpengaruh terhadap berpikir kritis peserta didik pada materi ekosistem. Tetapi dari hasil yang diperoleh kemampuan berpikir kritis peserta didik di SMP Negeri 16 
Mandai ada perbedaan antara kelas ekperimen dan kelas kontrol. Pada kelas eksperimen perhatian peserta didik lebih memperhatikan pada tahap melakukan pengamatan praktikum.

\section{KESIMPULAN}

Berdasarkan hasil penelitian menunjukkan (1) aktivitas belajar model STAD dengan pendekatan KPS berada pada kategori aktif, (2) aktivitas belajar model STAD dengan pendekatan CTL berada pada kategori cukup aktif, (3) kemampuan berpikir kritis model STAD dengan pendekatan KPS berada pada kategori tinggi, (4) kemampuan berpikir kritis model STAD dengan pendekatan CTL pada kategori sedang, (5) ada perbedaan yang signifikan aktivitas belajar model STAD dengan pendekatan KPS dan model STAD dengan pendekatan CTL, dan (6) ada perbedaan kemampuan berpikir kritis model STAD dengan pendekatan KPS dan model STAD dengan pendekatan CTL peserta didik di SMPN 16 Mandai Kabupaten Maros

\section{SARAN}

Berdasarkan hasil penelitian yang diperoleh, dikemukakan beberapa saran dalam upaya meningkatkan kemampuan berpikir kritis peserta didik dalam pembelajaran sebagai berikut: (1) diharapkan kepada guru IPA yang menerapkan pendekatan keterampilan proses mempersiapkan bahan yang akan digunakan dalam praktikum agar waktu pembelajaran dapat terlaksana sesuai rencana, (2) Diharapkan dalam penerapan pendekatan kontekstual materi disesuaikan dengan materi pembelajaran, (3) Sebaiknya dalam melakukan pembelajaran segala persiapan mulai dari perangkat perlu dipersiapkanm secara baik supaya tujuan pembelajaran dapat dicapai, (4) Sampel penelitian yang digunakan penelitian yaitu peserta didik kelas VII SMP Negeri 16 Mandai. Penulis berpendapat apabila penelitian sejenis ini dilakukan pada sampel yang berbeda, maka hasil yang akan diperoleh kemungkinan juga berbeda. Hal tersebut wajar terjadi karena karakteristik peserta didik tiap sekolah juga berbeda, sehingga hasil penelitian ini belum dapat digeneralisasikan secara universal untuk sampel yang berbeda, (5) Perlu ada penelitian lebih lanjut mengenai pendekatan keterampilan proses sains pada materi-materi yang IPA yang lain, dan (6) Kepada guru mata pelajaran IPA, diharapkan dapat menerapkan model pembelajaran STAD dengan pendekatan KPS untuk meningkatkan aktivitas dan kemampuan berpikir kritis peserta didik pada materi pengelolaan lingkungan

\section{DAFTAR PUSTAKA}

Depdikbud. 1993. Metode Penelitian Akta V. Depdikbud. Jakarta.

Djamarah, S. B, dan Zain, Aswan. 2002. Strategi Belajar Mengajar. Rineka Cipta. Jakarta. 
Hamalik, Oemar. 1994. Multimedia Pendidikan. PT.Citra Aditya Bakti. Bandung.

Idowu B, Ogunbodede E, dan Idowu B. 2003. Information and Communication Technology in Nigeria The Helath Sector Experience. Journal of Informatin Technology Impact. Vol 3, No. 2 (69-76).

Jackson, M. 2005. The Impact of ICT on the Development of Information Literacy. Journal of eLiteracy. Vol 2 (15-26).

Poerwadarminta, W.J.S. 1996. Kamus Umum Bahasa Indonesia. Balai pustaka Jakarta

Sadiman, A.m 2001. Interaksi Dan Motivasi Belajar Mengajar. Raja Grafindo Persada. Jakarta.

Sidin, R. Dan Mohammad S.N. 2007. ICT Dalam Pendidikan: Prospek dan Gambaran dalam Pembaharuan. Jurnal Pendidikan (139-152).

Slameto 1995. Belajar Dan Faktor-Faktor Yang Mempengaruhinya Reneka cipta Jakarta.

Sudjana, Nama, dan Rivai, Ahmatd 1997. Multi media Pembelajaran. Sinar Baru. Bandung. 